\title{
PENGEMBANGAN KURIKULUM PTAI YANG TERKAIT DAN SEPADAN DENGAN KURIKULUM MADRASAH
}

\author{
Syafruddin Nurdin \\ Guru Besar pada Fakultas Tarbiyah IAIN Imam Bonjol Padang \\ e-mail: syaf_nurdin@gmail.com
}

\begin{abstract}
One of the most important agendas of the current education is to link and match between curriculum across educational level and the job together with stakeholders. To link and match the curriculum of inter education level, it is necessary to understand the vision and mission, the institutional goal, the curriculum and its characteristics. Besides, it is also important to apply the general principles of curriculum development namely relevance, continuity, and integrated. Process of curriculum development is of the following steps: (1) identifying the determinant factors in the curriculum development and conducting Need Assessment; (2) identifying the competence or profile of the outputs; (3) identifying knowledge, attitudes, and skills that are necessary for the required competence; (4) arranging the Structure of Curriculum Program, and (5) developing syllabus.
\end{abstract}

Key words: development, Islamic Higher Education, Curriculum, Islamic school curriculum

\begin{abstract}
Abstrak: Salah satu agenda penting dunia pendidikan dewasa ini adalah menciptakan keterkaitan dan kesepadanan (link and match) kurikulum antar jenjang/ lembaga pendidikan, dan antara kurikulum lembaga pendidikan dengan dunia kerja dan stakeholders. Perwujudan link and match kurikulum antar jenjang/lembaga pendidikan perlu dipelajari dan dipahami visi-misi, tujuan lembaga, kurikulum dan karakteristiknya. Hal itu, yang tidak kalah pentingnya adalah menerapkan prinsip-prinsip umum pengembangan kurikulum yaitu relevansi, kontinuitas dan integrasi. Proses pengembangan kurikulum mengikuti beberapa langkah sebagai berikut; (1) mengidentifikasi faktor-faktor atau determinan yang turut menentukan pengembangan kurikulum, dan melakukan Need Assessment, (2) mengidentifikasi kompetensi/profil lulusan, (3) menentukan pengetahuan, nilai-sikap dan keterampilan yang diperlukan untuk membentuk kompetensi, (4) menyusun Struktur Program Kurikulum, dan (5) mengembangkan silabus.
\end{abstract}

Kata Kunci: pengembangan, PTAI, kurikulum, kurikulum Madrasah

\section{PENDAHULUAN}

Menciptakan keterkaitan dan kesepadanan (relevansi kurikulum) merupakan agenda penting yang harus dilakukan saat ini, karena lingkungan strategis dunia pendidikan bergerak dan terus berubah dalam kecepatan yang semakin tinggi. Pendidikan dihadapkan pada tantangan besar yaitu: (1) dunia berubah dengan laju yang semakin kencang, (2) kehidupan masyarakat, perekonomian, menjadi lebih kompleks, (3) sifat dasar pekerjaan berubah sangat cepat, (4) jenis-jenis pekerjaan menghilang dengan kecepatan tak terbayangkan, dan (5) masa lalu semakin tidak dapat dijadikan pedoman bagi masa depan (Colin Rose \& Malcolm Nichol, 1997).
Era industri mulai digantikan era informasi. "Kehidupan masya-rakat saat ini terkepung di antara dua era tersebut" (Ansyar dari Ornstein dan Hunkins, 1988: 323). Kemasyhuran dan kedigdayaan era industri pada gelombang kedua (second wave) sedang digantikan era informasi dari gelombang ketiga (third wave). Gelombang ketiga ini ditandai dengan terjadinya perubahan yang sangat cepat dalam kehidupan masyarakat sebagai dampak dari percepatan perkembangan ilmu pengetahuan dan teknologi, robohnya batasbatas antar negara sebagai dampak dari percepatan perkembangan telekomunikasi, menciutnya "jarak" antara satu tempat dengan tempat yang lainnya di permukaan bumi sebagai dampak dari kemajuan sarana transportasi, serta berubahnya secara drastis cara berpikir dan cara 
hidup manusia akibat pergaulan antar budaya yang semakin ekstensif. Iskandar Alisyahbana (Kompas, 28 Juni, 2002) mengatakan bahwa gelombang ketiga sebentar lagi akan digantikan era rekreasi dan hiburan. Pada saat itu dunia akan diramaikan dengan dibanjiri oleh industri hiburan dan kesenian.

Dunia pendidikan kita pada saat ini masih dihadapkan kepada beberapa pekerjaan rumah, yaitu soal pemerataan kesempatan belajar, relevansi, kualitas, efisiensi dan efektivitas pendidikan. Sekaitan dengan ini, Tilaar (1998: 49-51) mengidentifikasi sekurang-kurangnya ada delapan masalah pokok/utama (ARTA ARGADA PRADANA) yang sedang dihadapi, yaitu: (1) Menurunnya akhlak dan moral peserta didik, (2) Pemerataan kesempatan memperoleh pendidikan dan pemerataan kualitas pendidikan, (3) Rendahnya mutu pendidikan di berbagai jenjang dan jenis pendidikan, (4) Masih rendahnya efisiensi internal sistem pendidikan, (5) Masih rendahnya efisiensi eksternal sistem pendidikan dan pelatihan (6) Kelembagaan pendidikan dan pelatihan), (7) Manajemen pendidikan dan pelatihan yang belum sejalan dengan manajemen pembangunan nasional, (8) Sumber Daya Manusia (SDM) yang belum profesional.

Perkembangan studi Islam dalam dunia Islam, kini terjadi pula yang semakin pesat meluncur dari busur kelembagaannya. Di tengah produk pemikiran dunia seberang mengemuka di sini. Konon yang menjadi ironik, pasar pemikiran itu banyak dikonsumsi oleh kalangan di luar Perguruan Tinggi Agama Islam (PERTA VOL.VI/N0.01/2003). Banyak kalangan, termasuk dari kalangan dalam sendiri, diakui bahwa Perguruan Tinggi Agama Islam (PTAI) belum cukup mampu menghasilkan kualitas lulusan yang bermutu dan memberikan sumbangan dalam pengembangan masyarakat secara luas dan mendalam.

Menghadapi dan mengatasi tantangan tersebut, berbagai upaya pun telah dilakukan. Di antaranya sejumlah IAIN membuka jurusan dan program studi baru, baik yang masih dalam lingkup bidang ilmu-ilmu umum, yang terkait dengan pasar kerja atau minimal sesuai dengan tuntutan zaman, seperti ekonomi Islam, perbankan, publisistik, psikologi Islam, komputer dan sebagainya. Bahkah ada sejumlah IAIN yang sudah mengkonversi diri menjadi universitas seperti yang dilakukan oleh IAIN Syarif Hidayatullah Jakarta, IAIN Sunan Kalijaga Yogyakarta, IAIN Sunan Gunung Jati Bandung, IAIN Alauddin Ujung Pandang, IAIN Sultan Syarif Qasyim Pekanbaru, dan STAIN Malang.

Kelihatannya belum cukup dengan membuka jurusan dan program studi baru atau mengkonversi diri menjadi universitas, karena realita yang dihadapi PTAI sekarang ini jauh lebih mendasar dan kompleks. Sekurangkurangnya ada dua masalah pokok yang harus mendapat perhatian serius, yaitu persoalan sistem keilmuan atau pembidangan keilmuan (epistimology) yang dijadikan pijakan dan dikembangkan PTAI, dan bangunan struktur kurikulumnya.

Terkait dengan kurikulum PTAI, terlihat bahwa bangunan struktur kurikulum lembaga ini belum cukup mampu "mengubah" keadaan, padahal sebagai basis pengembangan pribadi/ individu semestinya kurikulum menempati posisi strategis dan penting serta mendapat prioritas tinggi dalam pendidikan. Karena, kurikulum merupakan satu komponen pendidikan yang terkait langsung dengan dasar pengembangan diri peserta didik agar bisa menjadi Sumber Daya Manusia (SDM) yang bermutu dan memiliki kompetensi yang diharapkan. Oleh karena itu, kurikulum PTAI perlu mendapat sentuhan reformasi dan rekonstruksi secara radikal.

Tantangan, masalah dan perubahanperubahan yang sedang terjadi, baik dalam lingkup nasional maupun dalam lingkungan PTAIN/S menghendaki adanya perubahan orientasi penyelenggaraan pendidikan yang semakin terkait dan sepadan (relevan) dengan perkembangan ilmu pengetahuan, teknologi dan seni, kebutuhan dunia industri, pasar kerja, dan kebutuhan pembangunan yang harus diikuti pula oleh perubahan kurikulum. "Ini berarti kurikulum yang berlaku sekarang perlu diperbaiki, disesuaikan, dan disempurnakan 
agar dapat menjawab tantangan dan perkembangan ilmu pengetahuan dan teknologi, dunia industri, pasar kerja, kebutuhan pembangunan serta kebutuhan masyarakat" (Fasli Jalal, 2002:2).

\section{KONSEP DAN PENGERTIAN KURIKU- LUM}

Kurikulum merupakan inti dari proses pendidikan, sebab di antara bidang-bidang pendidikan yaitu: manajemen, kurikulum, dan layanan siswa, kurikulum merupakan bidang yang paling langsung berpengaruh terhadap hasil pendidikan. Dalam pengembangan kurikulum, minimal dapat dibedakan antara "disain kurikulum" atau kurikulum tertulis (design, written, ideal, official, formal, document curriculum) dan implementasi kurikulum atau kurikulum perbuatan (curriculum implementation, curriculum in action, actual curriculum, real curriculum) (Nana Syaodih Sukmadinata, 2003:1).

Disain kurikulum dapat bersifat menyeluruh, mencakup semua rancangan dan komponen kurikulum seperti: dasar-dasar dan struktur kurikulum, sebaran mata pelajaran, Garis-Garis Besar Program Pengajaran (GBPP), program tahunan/smester, Silabus, Satuan Pelajaran (SP), Satuan Acara Perkuliahan (SAP), rancangan pengembangan media, sumber dan alat evaluasi, tetapi bisa juga hanya berkenaan dengan salah satu bentuk disain atau rancangan saja, umpamanya silabus atau GBPP.

Implementasi kurikulum, dapat meliputi seluruh kegiatan penerapan rancangan, seperti kegiatan pem-belajaran, pembimbingan, pelatihan, kegiatan ko dan ekstra kurikuler, field trips atau widyawisata, pengerjaan tugas-tugas, ulangan, ujian sampai dengan wisuda, atau hanya berkenaan dengan salah satu kegiatan saja seperti pembelajaran. Dengan demikian merupakan hal yang wajar apabila dalam masyarakat ada yang memandang kurikulum dalam arti yang luas (semua komponen rancangan dan implementasi) atau secara sempit, rancangan saja, itupun dibatasi lagi pada GBPP.

\footnotetext{
Kurikulum memiliki pengertian yang cukup kompleks, dan sudah banyak
}

didefinisikan oleh para pakar. Esensinya, kurikulum membicarakan proses penyelenggaraan pendidikan sekolah, berupa acuan, rencana, norma-norma yang dapat dipakai sebagai pegangan. Secara umum struktur kurikulum mempunyai empat komponen utama, yaitu: tujuan, materi/bahan (organisasi isi), proses belajar mengajar, dan evaluasi.

Dalam arti sempit kurikulum ditafsirkan sebagai materi pelajaran, sedangkan menurut pengertian yang luas, kurikulum dikatakan sebagai keseluruhan program lembaga pendidikan. Spektrum di antara dua kutub itu menafsirkan kurikulum sebagai perencana interaksi antara siswa dan guru untuk mencapai tujuan pendidikan (Miller and Saller, 1985:3). Pengertian yang tidak luas dan tidak terlalu sempit, pada dasarnya merujuk pada perencanaan kegiatan belajar mengajar guna mencapai tujuan sekolah. Pengertian kurikulum yang berada pada spektrum ini antara lain dikemukakan oleh; Finch and Crunkilton (1984); Tanner and Tanner (1980); Eisner and Vallance (1974); Taba (1962); Alberty (1962); dan Tyler (1949).

Pada Undang-Undang nomor 20 tahun 2003 tentang Sistem Pendidikan Nasional, kurikulum diartikan sebagai...." Seperangkat rencana dan pengaturan mengenai tujuan, isi, dan bahan pelajaran serta cara yang digunakan sebagai pedoman penyelenggaraan kegiatan pembelajaran untuk mencapai tujuan pendidikan tertentu" (Sinar Grafika, 2003:4).

Pengertian kurikulum di atas, secara eksplisit terlihat ada tiga komponen kurikulum, yaitu: tujuan, isi dan bahan pelajaran, serta cara atau metode yang digunakan sebagai pedoman penyelenggaraan KBM. Meskipun evaluasi tidak dinyatakan secara eksplisit, tapi frase cara yang digunakan sebagai pedoman penyelenggaraan kegiatan belajar mengajar secara implisit juga menyimpan arti tentang "evaluasi". Karena, kegiatan belajar mengajar pada hakikatnya diawali dengan perencanaan, diiringi dengan pelaksanaan (implementasi) dan diakhiri oleh penilaian atau evaluasi. Jadi evaluasi merupakan bagian integral dari sebuah kegiatan belajar 
mengajar, dan juga sekaligus merupakan salah satu komponen utama kurikulum.

Dengan demikian pengertian kurikulum yang terdapat dalam Undang-Undang Nomor 20 Tahun 2003 sudah mencakup keempat komponan utama kurikulum, yaitu: tujuan, isi dan bahan pelajaran atau materi, metode/cara, dan evaluasi.

\section{PROSES DAN LANGKAH-LANGKAH PENGEMBANGAN KURIKULUM}

Keputusan Menteri Pendidikan Nasional RI Nomor 232/U/2002 pasal 1 ayat 3 dan 4 ditetapkan bahwa terdapat dua jalur atau arah pendidikan tinggi: (1) Pendidikan Akademik, (2) Pendidikan Profesional. Pendi-dikan akademik terdiri atas program Sarjana, Magister, dan Doktor. Makin tinggi sifatnya, maka semakin kompleks kompetensi yang harus dikuasai. Sedangkan pendidikan profesional terdiri pula atas Diploma I, II, III dan IV, yang juga memiliki tingkatan/hirarkhi/kompetensi yang harus dipelajari.

Pengembangan kurikulum pada kedua jalur pendidikan di atas, perlu memperhatikan "prinsip relevansi", yang menekankan pada perlunya peserta didik dibekali dengan berbagai pengetahuan, nilai-sikap dan keterampilan (kompetensi) yang sesuai dengan tuntutan zaman dan tuntutan reformasi, guna menjawab tantangan dan globalisasi berkontribusi pada pembangunan masyarakat dan kesejahteraan sosial, lentur dan adaptif terhadap berbagai perubahan.

\section{PENGEMBANGAN KURIKULUM}

Diawali dengan mengidentifikasi faktorfaktor atau determinan yang turut menentukan pengembangan kurikulum, kemudian dilakukan analisa kebutuhan (Need Assessment) yaitu meneliti, mempelajari, membaca dan memahami kebutuhan, tuntutan, serta perkembangan yang terjadi di tengah-tengah masyarakat. Di samping itu, juga mengantisipasi kecenderungan (trend) perkembangan ilmu pengetahuan, teknologi dan seni, sehingga dengan demikian dapat diketahui kebutuhan pasar, lembaga pemakai lulusan (stakeholders) dan dapat pula diikuti arah serta kecenderungan perkembangan ilmu pengetahuan, teknologi dan seni pada masa depan.

Setelah diperoleh hasil dari Need Assessment, barulah dilakukan langkah selanjutnya yaitu; Merumuskan Tujuan Institusional (tujuan lembaga). Dalam hal ini, meliputi tujuan-tujuan Universitas, Institut, Sekolah Tinggi, Frakultas, Jurusan, dan Prodi. Dalam merumuskan tujuan institusi, hendaklah diakomodasi dan diapresiasi hasil Need Assessment, agar dapat menghasilkan kurikulum yang memiliki relevansi tinggi, baik dengan kebutuhan peserta didik, masyarakat, maupun dengan kebutuhan pembangunan serta perkembangan ilmu pengetahuan, teknologi dan seni. Perumusan tujuan institusional tidak boleh lepas dan menjauh dari rumusan tujuan pendidikan nasional. Artinya, rumusan tujuan institusional harus mengacu dan berorientasi kepada tujuan pendidikan nasional yang telah ditetapkan oleh Undang-Undang. Sehingga dengan demikian setiap lembaga pendidikan diharapkan dapat menghasilkan lulusan (out put dan out comes) yang sesuai dengan visi, misi dan karakteristik institusi/lembaga dan sejalan dengan cita-cita yang termaktub dalam UndangUndang Nomor 20 Tahun 2003 tentang Sistem Pendidikan Nasional, yaitu: " manusia yang beriman dan bertakwa kepada Tuhan Yang Maha Esa, berakhlak mulia, sehat, berilmu, cakap, kreatif, mandiri, dan menjadi warga negara yang demokratis serta bertanggung jawab (UU No. 20 Tahun 2003, Bab II, Pasal 3).

Kemudian, pada langkah berikutnya mengidentifikasi kompetensi yaitu menentukan kemampuan apa yang harus dimiliki lulusan setelah menyelesaikan proses pendidikan di sebuah lembaga/institusi. Artinya, kemampuankemampuan (kompetensi) apa saja yang mesti ada pada diri lulusan setelah ia menyelesaikan studi/kuliah pada sebuah lembaga/institusi pendidikan. Contohnya, kemampuan-kemampuan (kompetensi) apa saja yang harus dimiliki oleh seorang lulusan Lembaga Pendidikan Tenaga Kependidikan (LPTK) agama yakni jurusan/prodi Pendidikan Agama Islam (PAI) pada PTAIN/S. Lulusan jurusan/prodi PAI 
harus memiliki kompetensi:"Mengajarkan PAI pada sekolah dan madrasah" (kompetensi utama). Kemudian kompetensi pendukung lainnya seperti; (1) mendisain program belajarmengajar, (2) melaksanakan pembelajaran, (3) menilai proses dan hasil belajar, (4) mengelola kelas, (5) menggunakan media pembelajaran, dan (6) menguasai materi pembelajaran Fiqh, Al-Quran-Hadis, Tauhid/Aqidah, Akhlak, SKI, dan lainnya. Kompetensi-kompetensi di atas merupakan jawaban terhadap profil lulusan yang sudah dirumuskan sebelumnya yaitu "Menghasilkan Guru Agama yang Profesional untuk Sekolah Umum dan Madrasah".

Selanjutnya, langkah berikut adalah menentukan atau mengidentifikasi pengetahuan, nilai, sikap dan keterampilan (cognitive, affective dan psychomotoric) apa saja yang diperlukan untuk menghasilkan sejumlah kompetensi (utama, pendukung dan lainnya) yang telah ditetapkan di atas. Misalnya, untuk menghasilkan kompetensi utama "menjadi guru agama yang profesional pada sekolah dan madrasah" memerlukan sejumlah pengetahuan, nilai, sikap dan keterampilan. Pengetahuan dan keterampilan tentang bagaimana merumuskan kompetensi dasar yang spesifik, observable, terukur dalam Rencana Program Pembelajaran (RPP). Keterampilan mengelola kelas dan mengajukan pertanyaan-pertanyaan yang tepat kepada siswa dalam kegiatan belajar mengajar. Pengetahuan dan keterampilan dalam menggunakan metode dan media pembelajaran. Pengetahuan yang berkenaan dengan mata pelajaran Pendidikan Agama Islam, meliputi Fiqh, Hadis, al-Qur'an, Tauhid, Aqidah, Akhlak, Tarikh dan lainnya. Dan banyak lagi pengetahuan, nilai, sikap dan keterampilan yang memberi sumbangan kepada kompetensi utama, baik umum atau pun agama.

Langkah yang dilakukan adalah memilih dan menentukan "mata pelajaran/mata kuliah" yang akan diajarkan. Mata kuliah-mata kuliah apa saja yang dapat menghasilkan pengetahuan, nilai-sikap dan keterampilan bagi siswa/mahasiswa, sehingga mereka memiliki kompetensi seperti yang telah ditetapkan pada langkah ketiga di atas. Ini berarti, bahwa pemilihan dan penentuan mata kuliah haruslah didasari dan disesuaikan dengan tujuan lembaga dan kompetensi (utama) yang harus dimiliki oleh lulusan setelah ia menamatkan studinya. Bukan atas dasar interest dan kepentingan sepihak, diulangi bukan atas dasar interest dan kepentingan sepihak. Hal ini hendaknya menjadi perhatian pimpinan lembaga dalam melakukan pengembangan kurikulum dan silabus mata kuliah pada masing-masing jurusan dan program studi. Kemudian, mata kuliah-mata kuliah yang ditentukan/ditetapkan tersebut ditempatkan ke dalam sebuah Struktur Program Kurikulum, yang berisikan kolom-kolom antara lain; alokasi waktu, bobot SKS, sebaran mata kuliah, dan lainnya. Kemudian, barulah beranjak kepada penetapan dan penentuan siapa yang akan memegang apa. Dengan ini dimaksudkan adalah menetapkan dosen/staf pengajar yang paling tepat (relevan) untuk mengajarkan sebuah mata kuliah yang betulbetul sesuai dengan disiplin ilmu yang dimilikinya. Dalam penempatan agaknya sering dikatakan sebagai the right man on the right place, yaitu menempatkan seseorang sesuai pada tempatnya. Ini pun harus mendapat perhatian lembaga karena fenomena yang terlihat selama ini lebih banyak didaulat oleh budaya rikuh (ewuh pakewuh), ABS dan sebagainya. Sehingga banyak terjadi di perguruan tinggi ada mata kuliah yang tidak diajarkan oleh ahlinya, tapi lebih karena hubungan baik, klik, dan pertimbanganpertimbangan non akademis, sehingga akhirnya berujung dengan rendahnya kualitas hasil belajar (kompetensi) yang diperoleh mahasiswa dalam perkuliahan. Padahal setiap mata kuliah memiliki karakteristik tersendiri, baik dari segi penguasaan substansi materi, maupun dari sudut metodologi pembelajarannya.

Setelah menyelesaikan langkah kelima di atas, sampailah kita pada tugas untuk mengembangkan silabus, yang diawali dengan perumusan tujuan mata kuliah, identifikasi topik/pokok bahasan, dan penentuan/penetapan keluasan dan kedalaman materi (scope), uruturutan materi pelajaran yang akan diajarkan (sequence), referensi dan sebagainya.

\section{PENGEMBANGAN SILABUS}


Silabus merupakan pengembangan dan jabaran dari kurikulum, yang berisikan sinopsis mata kuliah dan kerangka materi pelajaran yang terdiri dari topik inti/pokok bahasan yang akan diajarkan dan dikuasai oleh mahasiswa.

Dalam silabus terdapat scope dan sequence kurikulum. Scope adalah ruang lingkup, cakupan, keluasan, dan kedalaman materi/ bahan pelajaran (perkuliahan). Sedangkan sequence adalah urut-urutan bahan/materi perkuliahan yang akan diajarkan. Selain dari itu, silabus biasanya dilengkapi pula dengan referensi atau buku-buku sumber, baik yang wajib atau pun penunjang/anjuran.

Silabus Mata Kuliah berisikan komponenkomponen, sebagai berikut:

\section{Identitas}

Identitas memuat bagian-bagian atau baris-baris untuk pengisian nama mata kuliah, kode mata kuliah, komponen mata kuliah, fakultas, jurusan, program studi, dan bobot mata kuliah. Identitas berada pada bagian atas atau bagian pertama dari silabus.

\section{Sinopsis Mata Kuliah}

Sinopsis mata kuliah merupakan paragraf pernyataan singkat yang berisikan garis-garis besar materi perkuliahan atau rangkuman pokok bahasan/sub pokok bahasan dari satu mata kuliah.

\section{Kompetensi Mata Kuliah}

Kompetensi mata kuliah adalah pernyataan tentang hasil belajar (learning outcomes) berupa pengetahuan, nilai-sikap, dan keterampilan yang diperoleh serta dikuasai mahasiswa setelah mengikuti perkuliahan.

\section{Indikator Kompetensi}

Indikator kompetensi merupakan jabaran karakteristik suatu kompetensi yang secara spesifik dapat dijadikan ukuran untuk menentukan dan menilai ketercapaian hasil belajar (learning outcomes).

\section{Topik/sub Topik}

Topik dan sub topik merupakan judul/sub judul yang mencerminkan isi atau materi kuliah yang konsisten dengan setiap kompetensi dasar. Dengan kata lain, dapat pula diartikan bahwa topik/sub topik adalah pokok-pokok materi kuliah yang harus dipelajari oleh mahasiswa sebagai sarana pencapaian kompetensi.

\section{Referensi}

Referensi adalah sumber kepustakaan berupa buku-buku atau sumber belajar, yaitu sumber materi/bahan kuliah yang digunakan dalam setiap topik/sub topik.

\section{PENGEMBANGAN KURIKULUM PTAI YANG RELEVAN DENGAN KURIKULUM MADRASAH}

Pengembangan kurikulum tidak dapat dilepaskan dari situasi yang terjadi di tengahtengah masyarakat, dan tidak dapat tidak harus merespon perkembangan ilmu pengetahuan, teknologi dan seni. Di samping juga harus memperhatikan perkembangan peserta didik sebagai subyek utama pendidikan.

Oleh karena itu, ada beberapa prinsip yang perlu dipahami dan diperhatikan dalam mengembangkan kurikulum. Prinsip-prinsip tersebut di antaranya; relevansi, kontinuitas dan integrasi.

\section{Prinsip Relevansi}

Dengan prinsip relevansi dimaksudkan kurikulum memiliki dua sayap kesesuaian, yaitu kesesuaian ke luar dan kesesuaian di dalam. Kesesuaian ke luar maksudnya adalah "tujuan, isi/materi/bahan, proses belajar mengajar (metode) dan evaluasi yang tercakup dalam kurikulum relevan dengan tuntutan, kebutuhan, dan perkembangan masyarakat serta perkembangan ilmu pengetahuan, teknologi dan seni.

Kurikulum juga harus relevan dengan kebutuhan, bakat dan minat, tingkat perkembangan peserta didik, sebab pada hakikatnya kurikulum itu diperuntukkan buat peserta didik bukan untuk guru/dosen dan orang tua. Kurikulum menyiapkan peserta didik untuk 
bisa hidup dan bekerja dalam masyarakat. Apa yang tertuang dalam kurikulum bukan hanya menyiapkan peserta didik untuk kehidupan sekarang, tetapi juga yang akan datang.

Kurikulum juga harus memiliki relevansi di dalam, yaitu ada kesesuaian atau konsistensi antara komponen-komponen kurikulum. Kesesuaian antara tujuan, isi, proses penyampaian, dan penilaian. Relevansi internal ini menunjukkan adanya suatu "keterpaduan kurikulum".

Relevansi kurikulum untuk setiap satuan pendidikan mempunyai titik berat yang berbeda. Untuk Sekolah Dasar (SD), relevansi kurikulum mengarah kepada bagaimana lulusan memiliki bekal yang sesuai untuk meneruskan ke Sekolah Lanjutan Tingkat Pertama (SLTP), serta bagaimana memperoleh materi muatan lokal yang sesuai dengan kondisi kebutuhan masyarakat. Hal ini juga dituntut pada tamatan SLTP agar mampu melajutkan ke Sekolah Lanjutan Tingkat Atas (SLTA) atau Sekolah Menengah Umum (SMU) dan menguasai jenis muatan lokal sesuai kondisi dan kebutuhan lingkungan. Sedangkan untuk SMU dan Madrasah 'Aliyah (MA) dititik beratkan kepada bagaimana mampu melanjutkan ke pendidikan tinggi. Khusus untuk Sekolah Menengah Kejuruan (SMK) link and match-nya terkait dengan dunia usaha dan industri.

Dalam kaitannya dengan pengembangan kurikulum PTAI, kesesuaian (relevansi) dititik beratkan kepada sejauh mana bekal berupa hasil belajar (learning outcomes) yang diperoleh mahasiswa selama mengikuti proses perkuliahan di PTAI baik negeri atau pun swasta bisa fungsional dalam kehidupan masyarakat, di lingkungan kerja (sekolah, madrasah, pondok pesantren). Artinya, peserta didik perlu dibekali dengan berbagai pengetahuan, nilai-sikap, dan keterampilan (kompetensi) yang sesuai dengan tuntutan zaman dan tuntutan reformasi, guna menjawab tantangan dan globalisasi berkontribusi pada pembangunan masyarakat dan kesejahteraan sosial, lentur dan adaptif terhadap berbagai perubahan.
Membicarakan soal keterkaitan dan kesepadanan (relevansi kurikulum) tidak dapat dilepaskan dari visi, misi, tujuan, serta karakteristik masing-masing satuan dan lembaga pendidikan. Karena, cita-cita, arah dan sasaran yang ingin dicapai oleh masingmasingnya sudah digariskan dan ditetapkan dalam kurikulum. Jadi, ke mana arah yang akan dituju oleh masing-masing satuan dan lembaga pendidikan itu sudah jelas. Idealnya, setiap satuan dan lembaga pendidikan harus konsisten dengan tujuan yang telah dirumuskan tersebut. Oleh karena itu, dalam membahas pengembangan kurikulum PTAI yang terkait dan sepadan dengan kurikulum Madrasah ini terlebih dahulu perlu diketahui tujuan program studi yang ada di PTAI (dalam hal ini prodi PAI pada Fakultas Tarbiyah), Madrasah 'Aliyah (MA) dan Madrasah 'Aliyah Keagamaan (MAK).

Dari informasi yang diperoleh sementara ini diketahui bahwa, tujuan program studi PAI adalah "menghasilkan guru agama yang profesional pada Sekolah dan Madrasah" (guru agama untuk jenjang pendidikan dasar dan menengah dan guru agama pada madrasah). Dengan penguasaan sekurang-kurangnya tujuh kompetensi dasar, yaitu; (1) memahami secara komprehensif wawasan pendidikan, menguasai substansi ilmu-ilmu keislaman dan metodologi pembelajaran, (3) menjadi guru agama Islam yang demokratis, (4) menjadi guru agama Islam yang profesional, (5) menjadi guru agama Islam yang responsif, inovatif, dan kreatif, (6) memiliki keterampilan dalam menerapkan wawasan pendidikan, (7) memiliki keterampilan mengembangkan kurikulum dan metodologi PAI.

Madrasah 'Aliyah (MA) yang sudah ditetapkan dan diakui sebagai Satuan Pendidikan yang berada pada jenjang Pendidikan Menengah dalam Undang-Undang Nomor 20 Tahun 2003, bab VI, pasal 19 (Sinar Grafika, 2003:10), bertujuan untuk:

a. Menyiapkan siswa untuk melanjutkan pendidikan pada jenjang pendidikan tinggi; 
b. Menyiapkan siswa agar mampu mengembangkan diri sejalan dengan perkembangan ilmu pengetahuan, teknologi dan kesenian yang dijiwai ajaran agama Islam;

c. Menyiapkan siswa agar mampu menjadi anggota masyarakat dalam mengadakan hubungan timbal balik dengan lingkungan sosial, budaya, dan alam sekitar yang dijiwai suasana keagamaan.

Selanjutnya, meskipun secara eksplisit penulis belum menemukan tujuan Madrasah 'Aliyah Keagamaan (MAK) yang spesifik, tapi jelas Satuan Pendidikan ini menyiapkan lulusannya untuk melanjutkan studi ke jenjang pendidikan tinggi, khususnya yang bernafaskan Islam (PTAI).

Setelah mencermati masing-masing tujuan dari Satuan Pendidikan di atas, dapat dikemukakan beberapa implikasi, sebagai berikut :

1) Program Studi PAI pada PTAIN/S menyiapkan lulusannya untuk bertugas sebagai guru agama pada sekolah umum dan madrasah (dapat dilihat pada kurikulum Prodi PAI pada PTAIN/S).

2) Madrasah 'Aliyah memang tidak secara khusus menyiapkan lulusannya untuk melanjutkan studi ke PTAI, bahkan ada kecenderungan lebih besar peluang bagi lulusan MA untuk meneruskan studinya ke perguruan tinggi umum (periksa struktur kurikulum MA yang dilandasi oleh PP Nomor 29 Tahun 1990 dan Kepmendikbud RI Nomor 0489/U/1992).

3) Madrasah 'Aliyah Program Keagamaan, meskipun tidak secara langsung dalam tujuan menyatakan lulusannya melanjutkan studi ke PTAI, tapi secara implisit dari kurikulum yang diimplementasikan/dikembangkan Satuan Pendidikan tersebut jelas bahwa lulusannya berpeluang besar untuk melanjutkan studi ke PTAI.
Dari implikasi yang dikemukakan di atas, terlihat bahwa untuk menciptakan keterkaitan dan kesepadanan (link and match) antara kurikulum PTAI (PAI) dengan kurikulum MA cukup besar terbuka peluang, karena MA Program Keagamaan orientasi kurikulumnya diarahkan kepada ilmu-ilmu keagamaan. Ini berarti, lulusannya diarahkan agar melanjutkan studi ke PTAI. Dengan demikian yang penting diperhatikan oleh kedua jenjang pendidikan (MAK dan PTAI) adalah persoalan "kontinuitas".

\section{Prinsip Kontinuitas}

Dengan kontinuitas dimaksudkan bahwa apa yang dipelajari (isi/materi kurikulum) di bangku kuliah pada PTAI adalah merupakan lanjutan dari apa yang telah dipelajari oleh siswa/peserta didik MAK. Sekali-kali jangan sampai terjadi apa yang dikuliahkan di PTAI adalah merupakan "pengulangan" dari apa yang telah dipelajari siswa di MAK. Bila "overlapping" seperti ini terjadi dalam perkuliahan di PTAI akan menimbulkan kejenuhan dan menghilangkan gairah mahasiswa untuk datang kuliah. Kontraproduktif seperti ini akan menimbulkan dampak negatif bagi perkembangan sebuah lembaga pendidikan. Sebaliknya bagi MAK juga harus memperhatikan bahwa apa yang diajarkan kepada siswa (isi/materi kurikulum) hendaknya sesuatu yang akan menjadi dasar dan mengantar mereka untuk mempelajari hal tersebut di PTAI.

Berkenaan dengan prinsip kontinuitas atau prinsip berkesinambungan tersebut, Nana Syaodih Sukmadinata (1988:168) membaginya kepada dua bagian, yaitu:

1. Berkesinambungan vertikal berarti antara jenjang pendidikan yang satu dengan jenjang pendidikan yang lebih tinggi dikembangkan kurikulumnya secara berkesinambungan tanpa ada jarak di antara keduanya, dari tujuan pembelajaran sampai tujuan pendidikan nasional dan begitu juga komponen yang lain harus berkesinambungan antara satu dengan lainnya. Berkesinambungan 
vertikal menuntut adanya kerjasama antara pengembangan kurikulum jenjang pendidikan dasar, menengah dan pendidikan tinggi.....

2. Berkesinambungan horizontal merupakan pengembangan kurikulum jenjang pendidikan dan tingkat/kelas yang sama tidak terputus-putus dan merupakan pengembangan yang terpadu.

Oleh karena itu, dalam mendisain, merancang, dan mengembangkan kurikulum kedua lembaga pendidikan terkait harus duduk satu meja guna untuk merumuskan dan menciptakan relevansi, integrasi, dan kontinuitas kurikulum. Sehingga dengan cara demikian akan terwujud keterkaitan dan kesepadanan (link and match) kurikulum pada kedua lembaga.

Sedangkan untuk menciptakan link and match antara kurikulum PTAI dengan MA agaknya dapat dilakukan pada beberapa mata pelajaran agama seperti; Aqidah-Akhlak- AlQur'an Hadis, Fiqh, san SKI. PTAI (FT/LPTK/PAI) sebagai produsen guru agama, haruslah mengembangkan kurikulum yang sejalan dengan kebutuhan MA (terutama yang terkait dengan mata pelajaran agama). Artinya, guru agama yang akan dihasilkan oleh LPTK (Prodi PAI) betul-betul menguasai mata pelajaran atau bidang studi keagamaan di atas sedemian rupa (mastery), baik substansi materi maupun metodologi pembelajarannya.

\section{Prinsip Integrasi}

Dalam kajian atau studi pengembangan kurikulum, sekurang-kurangnya dikenal 3 (tiga) macam/jenis kurikulum, yaitu: (1) child centered curriculum, (2) society curriculum, dan (3) academic centered curriculum.

Child centered curriculum adalah kurikulum yang memusat kepada peserta didik/siswa. Artinya, kurikulum yang memperhatikan kebutuhan, bakat, minat, dan pertumbuhan serta perkembangan peserta didik/siswa.
Society centered curriculum adalah kurikulum yang memusat kepada masyarakat. Maksudnya, kurikulum yang memperhatikan kebutuhan, tuntutan, dan perkembangan yang terjadi di tengah-tengah masyarakat.

Academic centered curriculum ialah kurikulum yang memusat kepada perkembangan ilmu pengetahuan, teknologi dan seni. Artinya, kurikulum yang sangat responsif terhadap perkembangan ilmu pengetahuan, teknologi dan seni.

Masing-masing macam/jenis kurikulum yang dikemukakan di atas merupakan sektor penting yang harus diperhatikan dalam pengembangan kurikulum. Tapi, jika pengembangan kurikulum hanya menekankan dan memusatkan (berorientasi) kepada salah satu jenis saja, maka besar kemungkinan akan menghasilkan lulusan yang memiliki pengetahuan tidak paripurna.

Pengembangan kurikulum yang menekankan sepenuhnya kepada tuntutan, kebutuhan, bakat, minat, pertumbuhan, dan perkembangan peserta didik/siswa, akan menghasilkan lulusan (out put) yang bagaikan "katak dalam tempurung". Artinya, merasa hebat dan pintar sendiri. Tidak tahu dan bahkan tidak kenal dengan perkembangan yang terjadi di tengah-tengah masyarakat, kemajuan dan perkembangan yang terjadi pada bidang ilmu pengetahuan, teknologi dan seni.

Demikian pula halnya, bila pengembangan kurikulum memberikan kepedulian dan perhatian semata-mata terhadap kepentingan, kebutuhan, tuntutan, dan perkembangan yang terjadi di tengah-tengah masyarakat, maka akan menggiring lembaga pendidikan menjadi "Pabrik". Menghasilkan lulusan sesuai dengan pesanan konsumen atau selera masyarakat.

Begitu juga kalau pengembangan kurikulum sepenuhnya ditujukan untuk merespon perkembangan ilmu pengetahuan, teknologi dan seni tanpa menghiraukan kebutuhan, tuntutan, bakat, minat dan perkembangan peserta didik/siswa, dan kebutuhan, tuntutan serta perkembangan masyarakat, maka sekolah atau perguruan tinggi 
akan menjadi lembaga sebagai penghasil "orang-orang berdasi" (white colour) yang intelek, tapi pintar cari duit di belakang meja. Artinya, menghasilkan orang-orang yang kaya dengan ilmu pengetahuan tapi "miskin spritual" (kehampaan spritual).

Dengan demikian dapat disimpulkan, bahwa idealnya pengembangan kurikulum memberikan tekanan yang seimbang kepada ketiga macam/jenis kurikulum (child centered, society centered, dan academic centered curriculum), agar dapat menghasilkan Sumber Daya Manusia (SDM) yang berkualitas dan paripurna.

\section{SIMPULAN}

Salah satu masalah pokok yang dihadapi dunia pendidikan kita pada saat ini adalah "relevansi", yaitu belum terdapatnya hubungan yang erat dan kuat antara dunia pendidikan dan lapangan kerja, dan dengan kualifikasi yang dituntut oleh lapangan kerja, baik di tingkat nasional mapun internasional dalam menghadapi era globalisasi dan pasar bebas.

Upaya mewujudkan atau menciptakan keterkaitan dan kesepadanan (link and match) antara kurikulum lembaga pendidikan, dan antara kurikulum lembaga pendidikan dengan dunia kerja dan stakeholders, merupakan pekerjaan penting yang perlu diagendakan saat ini.

Secara umum pengembangan kurikulum mengikuti proses dan langkah-langkah sebagai berikut: (1) mengidentifikasi faktor-faktor atau determinan yang turut menentukan/ mempengaruhi pengembangan kurikulum, (2) merumuskan tujuan lembaga (institusional) yang diformulasikan dalam bentuk "profil lulusan", (3) mengidentifikasi dan menetapkan kompetensi lulusan, (4) mengidentifikasi/ menentukan pengetahuan, nilai-sikap, dan keterampilan apa yang harus dimiliki peserta didik untuk meraih kompetensi lulusan, (5) Menetapkan mata kuliah, bobot, dan sebarannya dalam sebuah Struktur Program Kurikulum, termasuk di dalamnya menentukan dosen/staf pengajar yang akan mengampu mata kuliah.
Terakhir dikembangkan menjadi silabus mata kuliah.

Dalam mengembangkan kurikulum PTAI (Prodi PAI) yang terkait dan sepadan (relevan) dengan kurikulum Madrasah, perlu dipelajari dan dipahami visi-mislebih besar peluang untuki, dan tujuan lembaga, kurikulum dan karakteristiknya. Antara kurikulum PTAI (Prodi PAI) dan kurikulum MAK lebih besar peluang untuk diciptakan keterkaitan dan kesepadanan. Sedangkan antara MA dan prodi PAI dapat diciptakan link and match, terutama pada mata pelajaran/bidang studi agama (Aqidah-Akhlak, Al-Qur'an-Hadis, Fiqh, dan SKI).

Di samping itu, penerapan prinsip-prinsip umum pengembangan kurikulum relevansi, kontinuitas, dan integrasi, merupakan syarat penting dalam mewujudkan keterkaitan dan kesepadanan antara lembaga pendidikan dengan dunia kerja.

\section{DAFTAR RUJUKAN}

Andi Haris Prabawa, Siti Zuhriah. (ed). 2002. Paradigma Pengembangan Kurikulum Tahun 2002. Surakarta: Muhammadiyah University Press.

Ansyar, M. 2003. Hakekat Kurikulum Berbasis Kompetensi: Implementasi pada Kurikulum Pendidikan Tinggi. (Makalah Seminar Kurikulum Berbasis Kompetensi IAIN Imam Bonjol Padang).

Brady, Laurie. 1992. Curriculum Development. New York: Prentice Hall.

Departemen Agama RI. 1998. Kurikulum Madrasah 'Aliyah Tahun 1994: Landasan Program, Program dan Pengembangan. Jakarta: Dirjen Binbaga Islam Depag RI.

E. Mulyasa. 2002. Kurikulum Berbasis Kompetensi: Konsep, Karakteristik, dan Implementasi. Bandung: Remaja Rosdakarya. 
Fasli Jalal. 2002. Sambutan Pembukaan Seminar Nasional KBK di UNP. Padang.

Hamid Hasan. 2002. Hakekat Kurikulum Berbasis Kompetensi. (Makalah dalam Seminar Nasional KBK UNP).

Husni Rahim. 2001. Arah Baru Pendidikan Islam di Indonesia. Jakarta: PT. Logos Wacana Ilmu dan Pemikiran.

Nana Syaodih Sukmadinata. 1997. Pengembangan Kurikulum: Teori dan Praktek. Bandung: Remaja Rosdakarya.

Nana Syaodih Sukmadinata. 2003. Dasar-Dasar Pengembangan Kurikulum perguruan Tinggi. (Makalah dalam Lokakarya Pengembangan Kurikulum Berbasis Kompetensi IAIN Sunan Gunung Jati Bandung).

Rose, Colin \& Malcom J. Nicholl. 2002. Accelerated Learning For The 21 st Century. Bandung: Nuansa.
Sinar Grafika. 2003. Undang-Undang RI Nomor: 20 Tahun 2003 tentang Sistem Pendidikan Nasional. Jakarta.

Soediyarto. 1993. Memantapkan Sistem Pendidikan Nasional. Jakarta: PT. Gramedia Wirasarana.

Tilaar, H.A.R. 1998. Beberapa Agenda Reformasi Pendidikan Nasional: Dalam Perspektif Abad 21.

Tyler, Ralph W. 1949. Basic Principle of Curriculum and Instruction. Chicago: Chicago Press. 